\title{
University-Industry Interaction Trends in the Baltic Sea Region: A Bibliometric Analysis ${ }^{1}$
}

\author{
Elena Murashova \\ Valeria Loginova \\ School of Economics and Management. \\ The Pacific National University \\ Tikhookeanskaya 136. \\ Khabarovsk 680035 . Russia \\ E-mail: elena.murashova898@gmail.com \\ E-mail: ler_log@mail.ru
}

Abstract: The main objective of this study is to summarise and analyse the level of scientific interest from researchers from the Baltic Sea Region in interacting with each other on scientific and research projects in university-industry interaction field. This study will use bibliometric analysis based on actual joint initiatives and their published results. The growth of interest from both universities and industry in joint initiatives and changes in the nature of their cooperation (Butcher \& Jeffren, 2005) has led to a significant increase in the Baltic Region and the number of scientific publications has doubled in the years 2010-2014. However, compared to the number of similar published studies from the United States, the United Kingdom, China and Japan, those results far outnumber the achievements of the Baltic regions. At the same time, there has been significant increase in the number of studies undertaken by Sweden, Germany and Finland in the period from 2012 to 2014, facilitated by active international and interdisciplinary cooperation and involvement in the research by a large number of authors. The results of the evaluation indicators through this bibliometric analysis can assist in the specific targeting and allocation of available finance and funding into promising fields of research and aid in communication and cooperation between stakeholders and interested organisations.

The research was supported by the Erasmus Mundus Action 2. Ref. 372117-1-2012-1-FI-ERA MUNDUS-EMA21. 
Keywords:Baltic Sea Region, bibliometric analysis, university-industry collaboration, university-industry interaction

\section{Introduction}

Profound changes in the world economy, transition from the industrial era to the post-industrial era, formation of a new type of economic system, which is a hybrid variant of the organisation of production and management and includes the cluster-network structure with horizontal links and collaboration mechanism (Smorodinskya, 2012), also changes the nature of the networking partnership between universities and business, significantly increasing the role of universities. In the process of interaction with business, university shifts to the "third mission" (Mowery \& Sampat, 2005), where, being business-oriented, it contributes to the creation of new enterprises, transfer of technologies and commercialisation (Alcaraz-Rodriguez et al., 2014; Muravska et al., 2012; Säär \& Rull, 2015). University plays an important role as the source and the disseminator of new knowledge and technologies that meet the requirements of a modern economy and it can also play a more active role in the field of innovation in an increasingly knowledge-based society (Etzkowitz \& Leydesdorff, 2000). In recognition of this fact, the governments of many industrially developed countries since 1970 have started numerous initiatives aimed at interconnecting the universities with industrial innovations (Mowery \& Sampat, 2004). Many of these initiatives are focused on the stimulation of local economic development on the basis of scientific research at universities.

The initiatives of the European Union, aimed to increase the innovative capacity and global competitiveness of the Baltic Sea macro-region, which are reflected in the EU Strategy for the Baltic Sea Region approved in 2009 (Communication $\operatorname{COM}(2009) 248$ final), are no exception to this. Among the key priority areas of the Action Plan the following stands out: "To exploit the full potential of the region in research and innovation; Implementing the Small Business Act: To promote entrepreneurship, strengthen SMEs and increase the efficient use of human resources" (Communication COM(2009) 248 final). According to Smorodinskaya (2012), the heterogeneity of macro-region's economic space within the framework of this strategy is viewed as an opportunity for mutually supportive cooperation of potentials of countries with developed economies (Scandinavia and Germany) and countries with transition economies (the Baltic States and Poland). The potential of the developed economies of Scandinavia 
and Germany can serve as a driver for strengthening the collaboration between universities and business in the Baltic countries and Poland. A substantial role is given to strengthening the cooperation network between science, business and government, as well as to developing the Triple Helix (Etzkowitz, 2003), in which all three institutional spheres - universities, business and governmentstill retain their traditional mission but begin to play a new role, fulfilling the functions of other institutional spheres, with the university serving with an increasing frequency as an influential and equal partner in the Triple Helix (Etzkowitz, 2011; Muravska \& Prause, 2012). New initiatives arising from these networks become a source of innovation policies at national, sub-national and supranational levels (Etzkowitz, 2003). In the emerging new economic, political and social environment, the university-industry interaction becomes a subject of considerable interest from researchers, politicians, entrepreneurs and universities. One of the proofs of this interest is the results of assessment of the level of innovation development of countries in the evaluation of the global competitiveness of the countries where the "University-industry collaboration in R\&D" is adopted as a special parameter of competitiveness (Table 1).

Finland, Germany, Sweden, Norway, Denmark maintain high world country rankings of global competitiveness in terms of development of cooperation between universities and industry in the field of $R \& D$, remaining in the top twenty during the period of 2006-2015, which indicates a high level of cooperation between universities and industry in the field of R\&D in these countries. According to assessment from the period of 2014-2015, Finland takes the first place in the top ten leaders of the global competitiveness among 144 countries with a score of 6.0 (out of 7.0 possible). Other places in the top ten are traditionally left to Sweden and Germany, and the lowest position in this group of countries based on the analysed index is taken by Poland (Table 1).

As another proof of the high interest in the topic of university-industry interaction, we propose to consider the position of the countries of the Baltic Sea Region among the countries of the world based on data from the Global Innovation Index (The Global Innovation Index, 2015), where the universityindustry collaboration in research (Fig. 1) is one of the parameters, and which is drawn on the basis of survey findings in relevant countries on the extent of cooperation between businesses and universities in the field of research. 
Table 1. The dynamics of university-industry collaboration in R\&D index assessment in the countries of the Baltic Sea Region

\begin{tabular}{|l|c|c|c|c|c|c|c|c|}
\hline Country & $\begin{array}{c}\mathbf{2 0 0 6 -} \\
\mathbf{2 0 0 7}\end{array}$ & $\begin{array}{c}\mathbf{2 0 0 8 -} \\
\mathbf{2 0 0 9}\end{array}$ & $\begin{array}{c}\mathbf{2 0 0 9 -} \\
\mathbf{2 0 1 0}\end{array}$ & $\begin{array}{c}\mathbf{2 0 1 0 -} \\
\mathbf{2 0 1 1}\end{array}$ & $\begin{array}{c}\mathbf{2 0 1 1 -} \\
\mathbf{2 0 1 2}\end{array}$ & $\begin{array}{c}\mathbf{2 0 1 2} \\
\mathbf{2 0 1 3}\end{array}$ & $\begin{array}{c}\mathbf{2 0 1 3} \\
\mathbf{2 0 1 4}\end{array}$ & $\begin{array}{c}\mathbf{2 0 1 4 -} \\
\mathbf{2 0 1 5}\end{array}$ \\
\hline $\begin{array}{l}\text { Total number } \\
\text { of countries } \\
\text { included in the } \\
\text { assessment }\end{array}$ & 125 & 134 & 133 & 139 & 142 & 144 & 148 & 144 \\
\hline Denmark & $15 / 4.7^{*}$ & $7 / 5.3$ & $6 / 5.5$ & $8 / 5.3$ & $15 / 5.2$ & $21 / 4.9$ & $10 / 4.8$ & $20 / 4.9$ \\
\hline Estonia & $28 / 3.9$ & $29 / 4.0$ & $32 / 4.1$ & $36 / 4.2$ & $34 / 4.3$ & $34 / 4.4$ & $45 / 3.5$ & $34 / 4.4$ \\
\hline Finland & $3 / 5.5$ & $4 / 5.5$ & $3 / 5.6$ & $3 / 5.6$ & $4 / 5.6$ & $4 / 5.6$ & $3 / 5.6$ & $1 / 6.0$ \\
\hline Germany & $5 / 5.3$ & $6 / 5.4$ & $10 / 5.2$ & $9 / 5.2$ & $13 / 5.2$ & $11 / 5.2$ & $4 / 5.5$ & $10 / 5.3$ \\
\hline Iceland & $21 / 4.5$ & $15 / 5.0$ & $17 / 4.8$ & $16 / 5.0$ & $17 / 5.0$ & $20 / 4.9$ & $35 / 3.7$ & $25 / 4.6$ \\
\hline Latvia & $51 / 3.2$ & $83 / 3.0$ & $86 / 3.2$ & $73 / 3.5$ & $57 / 3.8$ & $59 / 3.7$ & $70 / 3.1$ & $63 / 3.7$ \\
\hline Lithuania & $55 / 3.2$ & $53 / 3.5$ & $45 / 3.8$ & $35 / 4.2$ & $31 / 4.4$ & $29 / 4.5$ & $63 / 3.1$ & $27 / 4.6$ \\
\hline Norway & $18 / 4.6$ & $17 / 4.9$ & $15 / 4.9$ & $20 / 4.9$ & $22 / 4.8$ & $19 / 5.0$ & $19 / 4.6$ & $15 / 5.0$ \\
\hline Poland & $38 / 3.6$ & $81 / 3.0$ & $76 / 3.3$ & $64 / 3.6$ & $65 / 3.6$ & $67 / 3.6$ & $103 / 2.8$ & $73 / 3.5$ \\
\hline Sweden & $2 / 5.5$ & $3 / 5.6$ & $5 / 5.6$ & $5 / 5.5$ & $5 / 5.5$ & $7 / 5.4$ & $7 / 5.3$ & $11 / 5.3$ \\
\hline
\end{tabular}

* The numerator shows rank. the denominator shows points.

Source: Authors' construction based on the Global Competitiveness Report. 2006; 2008; 2009; 2010; 2011; 2012; 2013; 2014

Figure 1 shows minute changes in the positions of individual countries of the Baltic Sea Region over the last five years (2010-2015), Finland (5.97), Sweden (5.33), Norway (5.02) maintained and strengthened their leading positions in 2015, characterising the degree of cooperation between businesses and universities in the field of joint research. The scores received by these countries are significantly higher than the average score for the Baltic Sea Region group of countries (4.61 in 2010; 4.73 in 2015), as well as the average score of the EU countries (4.22 in 2010; 4.38 in 2015) (The Global Innovation Index, 2015). This marks active cooperation between businesses and universities. The lowest positions in 2015 are occupied by Estonia (4.36), Latvia (3.67) and Poland (3.5), where the scores are below the average for both the Baltic countries and the EU countries, that is, in these countries the level of cooperation is significantly lower. In earlier studies (Jones-Evans et al., 1999) it has been proven that sustainable competitiveness will depend on technological strengths, or strengths based on innovation, such as the ability to apply new technologies, development of new products in order to gain access to new markets, implementation of 
Figure 1. The Global Innovation Index: University/industry research collaboration in 2010-2015, average score, from 1 to 6

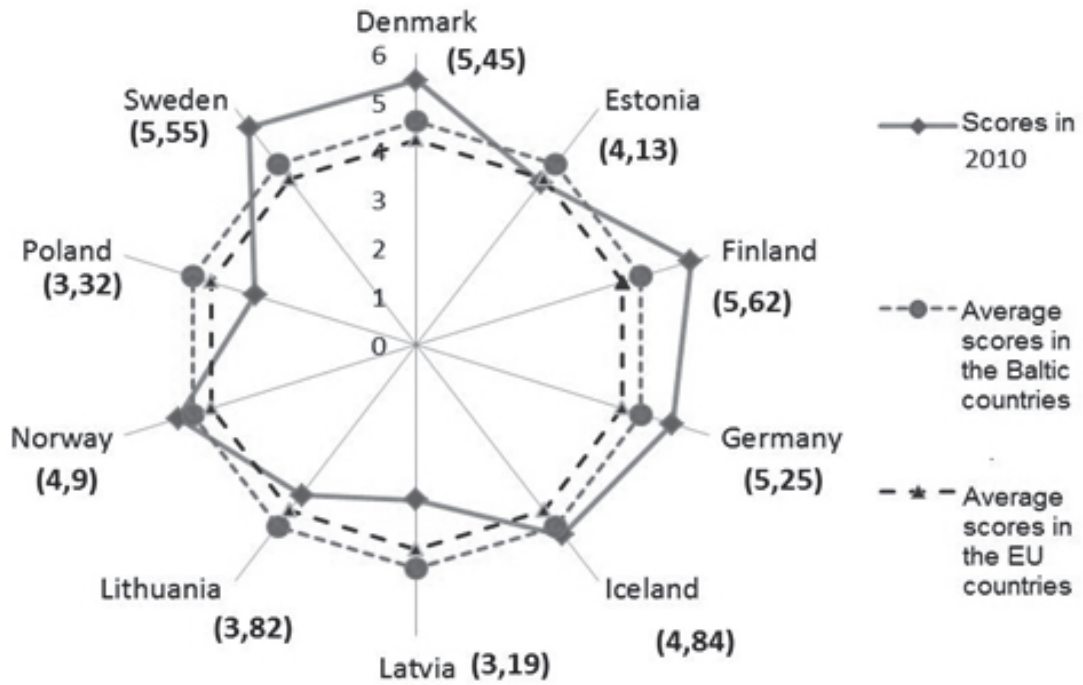

a) 2010

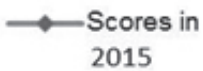

$-\$$ - Average scores in the EU countries the Baltic countries

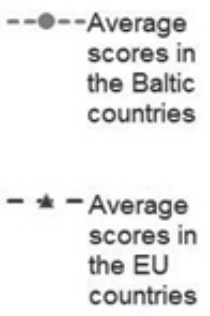

b) 2015

Source: Authors' construction based on the Global Innovation Index, 2015

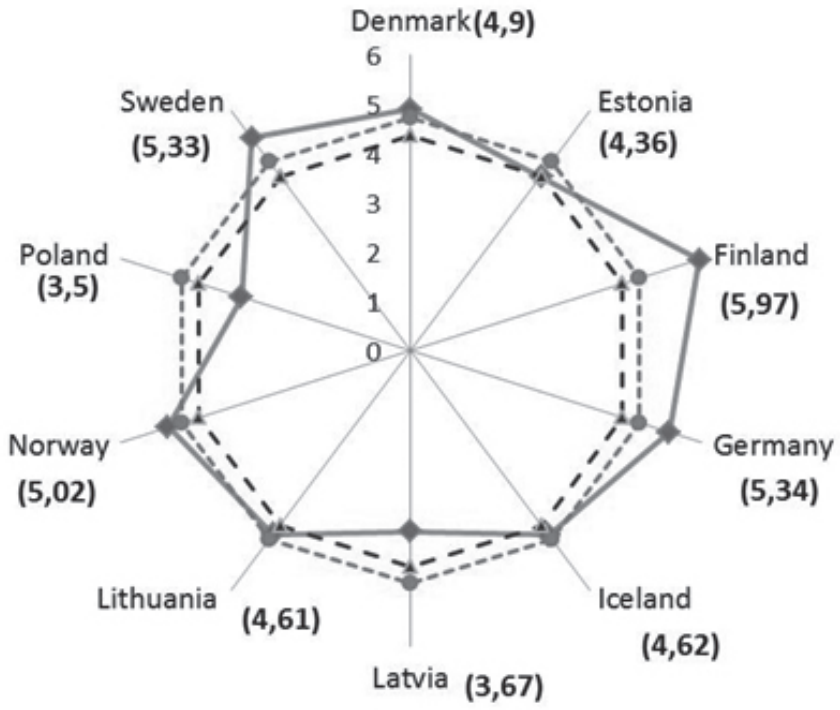


the best practices in business management, as well as increasing the skill level throughout the whole spectrum of the labor force, and this dependence on technological development for the future national competitive advantage can be particularly pronounced in the peripheral regions of Europe, such as some countries in the Baltic region.

Indeed, one of the main reasons for the relatively weak development of the technology sector in some countries of the Baltic region as compared to other more developed countries may be a lack of cooperation with local science and technology infrastructure, particularly in the university sector.

Some analysts have formulated a statement that many of the major technological advances and innovations were the result of close cooperation between universities and industry (Polt, 2001; Hameri, 1996; Senker, 1998; and others). In addition, the researchers found that the contributions of the scientific community to innovations most commonly takes the form of indirect and intangible flows of ideas, knowledge and expert assistance, and also came to the conclusion that the main way to increase the contribution of universities in innovation is to expand the communication channels between science and industry (Senker, 1998; Scott, 2001), including joint ventures, exchanges of personnel, licenses, patents, internships, joint scientific publications and others. Moreover, Calvert and Patel (2002) noted that the joint scientific publications have been used as an indicator of the joint work of universities and industry in the UK for more than 20 years, and found a rapid increase in the volume of such cooperation since 1980 .

The main objective of the article is to show the results of the level of scientific interest of researchers from the Baltic Sea Region to the issues of interaction between the university and industry, and focus on the main trends of scientific cooperation in this field, using bibliometric analysis based on scientific publications. The authors, however, do not intend to answer the question of whether the bibliometrical standards sometimes violate academic freedom as the basic right of scholars (Kerikmäe et al., 2016).

We believe that among the countries of the Baltic Sea Region, Scandinavian countries and Germany will maintain the dominant role in the formation of scientific interest in the issues of university-industry collaboration, and that the most dynamic period of scientific activity could fall on the period of 2011-2014, when the initiatives of the European Commission provided stronger incentives and pressure to conduct research in these areas. To test the stated hypothesis, the authors consider it necessary to: 
1) study the global trends in publication activity on the researched topic;

2) define the place of the Baltic Sea Region countries amidst the global trends;

3) determine the sectorial fields in matters of university-industry collaboration;

4) provide insight into the avenues of research in the study of universityindustry collaboration;

5) examine the degree of influence of parameters, characterising research and development, on the publication activity of individual countries.

\section{Methodology and data}

As the article's focus is a topical research area, the authors have chosen a scientific method to approach the matters of collaboration between universities and business, and have applied bibliometric analysis as the primary method of data collection in this study. All bibliometric estimates are based on information obtained from publications that are indexed by the abstract database Scopus. ${ }^{2}$ The main bibliographic information refers to publications, classified as 'research paper' and 'review article'. The Scopus database is not complete, as there are many other scientific databases for journals around the world, and it focuses mainly on English-language publications. Consequently, as a rule, the Scopus database does not incorporate publications in national languages and this limits the selection of scientific publications for research. Since bibliometric data on the basis of Scopus is not fully comprehensive and accurate, any assessment should always be conducted while taking into account statistical error (Holmes, 2014).

'University-industry collaboration' and 'university-industry interaction', mentioned in the title, abstract and keywords across all the logs available in the abstract database, were used as keywords for searching for documents. In the context of the research, the search terms 'university-industry collaboration' and 'university-industry interaction' were regarded as synonyms describing common interests or efforts in matters of relations between universities and industry (Merriam-Webster, n.d.).

Known bibliometric indicators of the abstract database in question were used for this work during the search for documents, including 'Documents by year', 'Documents by affiliation'. 'Documents by country/territory', and 'Documents by subject area'.

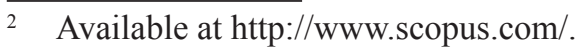


The theory and practice of researching scientific publications based on bibliometrics first became widespread in scientific research when the term 'statistical bibliography' was replaced by bibliometrics (Pendlebury, 2008; Feng et al., 2015). Historically, bibliometric methods have been used to trace the rate of citation of academic journals. Today, by using bibliometric analysis researchers can quickly understand the state of research and are able to predict the possible directions the research could take in the future (Morris, 2002). Bibliometrics help examine, organise and analyse large amounts of historical data and help analysts identify "hidden patterns" that may help researchers in the process of decision-making. There are several important works (Morris, 2002; Kostoff et al., 2001; Feng et al., 2015), where the authors, using information from databases and system analysis in the form of DIVA software, database tomography or CiteSpace, visualise documents as clusters on the bidimensional map and thus have the opportunity to study interrelations between documents and clusters of documents, to formulate summary data on each cluster of documents and, correspondingly, to give an idea about the trends and projections in the field of related scientific interests.

Due to the fact that the practice of using bibliometry is widespread enough and that using bibliometric analysis as a method of quantifying these kinds of processes is not something new, in this study we attempted to organise the data and determine the nature of tendencies and patterns in the priorities of the researchers from the countries of the Baltic Sea Region in the new conditions of integration of these countries. There is ample evidence that one of the suitable methods for quantitative evaluation of the degree of cooperation between universities and industry (Katz \& Martin, 1997; Calvert \& Patel, 2003; Butcher \& Jeffrey, 2005; Diem \& Wolter, 2011; Feng et al., 2015) is to estimate the amount of joint scientific publications on the basis of bibliometric analysis using different databases (Web of Science, Scopus, Google Scholar, and others). The amount of publications submitted to the database provides a quantitative measure of individual production of researches (Diem \& Wolter, 2011), as well as a partial reflection of the science and research collaboration (Calvert \& Patel, 2003).

Key measuring indicators of the global abstract databases, characterising the publication activity, allow to effectively evaluate the level of scientific interest in the test region regardless of territorial jurisdiction, time period, structural changes in the field of study, or degree of cooperation between parties interested in scientific cooperation. 
The conducted research (Qin et al., 1997; Katz \& Martin, 1997; Calvert \& Patel, 2003; Butcher \& Jeffrey, 2005) allows to identify the trends typical of the present. On the one hand, it is the increasing interest in such a method of evaluation as bibliometric analysis due to the general public accessibility and a high degree of systematisation of information databases and increase in the number of papers co-authored by three or more people that may characterise a wide involvement, interaction and exchange of knowledge among researchers in one area. On the other hand, Katz and Martin (1997) insist on the conceptual distinction being made between cooperation and co-authorship, because in many different situations of interaction co-authorship can actually take place without a substantial degree of scientific cooperation and collaboration may occur without the joint publication (Calvert \& Patel, 2003). which can be practically difficult to assess. Another disadvantage of this method is a possible double-counting of articles as an article may be subject to more than one disciplinary area. Therefore, it is necessary to combine bibliometric measures with qualitative data and use a variety of qualitative and quantitative research methods.

During the study, the authors have drawn on secondary data on a number of key parameters, important for assessment, in particular:

- University-industry collaboration in R\&D index (the Global Competitiveness Report);

- The Global Innovation Index;

- Main Science and Technology indicators;

- The total number of publications by countries worldwide;

- The share of scientific publications in accordance with international cooperation by countries worldwide;

- The total number of publications by the countries of the Baltic region;

- The share of scientific publications in accordance with interregional cooperation (Baltic region) by the countries of the region;

- The total number of publications by specific universities in the countries of the Baltic region;

- The share of publications by fields of research and structural changes in the countries worldwide;

- The share of publications by fields of research in the countries of the Baltic region;

- Actual directions of the subject areas based on the citation results;

- The share of joint documents in accordance with institutional cooperation (companies, universities, research institutions). 
In addition, we have compiled an interdisciplinary data characterising the national identity (country, region), disciplinary (sectoral field, subject area by the rate of citation) and institutional (university, industry) affiliation where possible. The results are presented in the following section.

For our analysis we examined the trends in scientific publications on the issues of cooperation between universities and industry in the countries of the Baltic Sea Region, which refers to the countries around the Baltic Sea: the Baltic countries (Estonia, Latvia and Lithuania), the Nordic countries (Denmark, Iceland, Norway, Finland and Sweden), northern Germany and northern Poland (BSR STAR, 2015). Some of these countries-Denmark, Estonia, Finland, Germany, Latvia, Lithuania, Poland and Sweden - are members of the European Union (Communication $\operatorname{COM(2009)~} 248$ final). For the analysis we included only those regions that are tightly integrated with other regions around the Baltic Sea, Iceland and Norway are included because they have a close relationship with many of the countries around the Baltic Sea, and they are prepared to participate in regional cooperation. It should be added that despite the fact that the countries are located in the same region, there are significant differences between the Baltic countries, Nordic countries, Germany and Poland in terms of industrial development and the concentration of technological innovations, including those in the field of higher education (Table 2).

In Finland and Sweden, the share of expenses allocated to R\&D (3.55\% and $3.41 \%$, respectively) is higher compared to Norway, Poland and Estonia. In 2012, Finland, Sweden and Denmark also had a higher share of researchers and staff involved in R\&D (Table 2). Furthermore, in the same countries more than two thirds of the R\&D expenses were covered by companies $(68.7 \%, 67.8 \%$ and $65.7 \%$, respectively). On the other hand, Poland (34.4\%) and Estonia (32.1\%) allocate a higher percentage of gross expenditure to R\&D in the higher education sector than Finland (21.6\%) and Germany (18.0\%) and other countries, which can be characterised as an untapped resource in the university sector in Poland and Estonia, in particular in terms of the potential for closer cooperation with the industry (Table 2).

Differences in the main science and technology indicators by country have an impact on the state of scientific research in countries, resulting in differences in quantitative and qualitative indicators and in the main trends of publication activity of the surveyed countries.

The time frame for research on the global tendencies of publication activity in the field of interaction between universities and industry is limited by the period 
from 1972 to 2014, which was characterised by a maximum dissemination of research results in this field of study. The search period for assessment of trends in the countries of the Baltic Sea Region is limited to the period 2004-2014 due to the accession of Estonia, Latvia and Lithuania to the European Union in 2004.

Table 2. Main science and technology indicators. 2012

\begin{tabular}{|c|c|c|c|c|c|c|c|}
\hline Indicators & Denmark & Estonia & Finland & Germany & Norway & Poland & Sweden \\
\hline $\begin{array}{l}\text { Gross Domestic } \\
\text { Expenditure on R\&D } \\
\text { (GERD) as \% of GDP }\end{array}$ & 2.98 & 2.19 & 3.55 & 2.98 & 1.65 & 0.9 & 3.41 \\
\hline $\begin{array}{l}\text { Total researchers } \\
\text { in full-time equiva- } \\
\text { lent/1,000 labour force }\end{array}$ & 13.6 & 7.6 & 16.1 & 8.4 & 10.4 & 4.3 & 10.7 \\
\hline $\begin{array}{l}\text { Total R\&D person- } \\
\text { nel/1000 labour force }\end{array}$ & 20.1 & 9.7 & 21.4 & 14.2 & 14.1 & 5.9 & 17.6 \\
\hline $\begin{array}{l}\% \text { of GERD performed } \\
\text { by the Business Enter- } \\
\text { prise sector }\end{array}$ & 65.7 & 57.5 & 68.7 & 67.8 & 52.3 & 37.2 & 67.8 \\
\hline $\begin{array}{l}\% \text { of GERD performed } \\
\text { by the higher education } \\
\text { sector }\end{array}$ & 31.8 & 32.1 & 21.6 & 18 & 31.3 & 34.4 & 27.1 \\
\hline $\begin{array}{l}\text { Business Enterprise } \\
\text { expenditure on R\&D as } \\
\% \text { of GDP }\end{array}$ & 1.96 & 1.26 & 2.44 & 2.02 & 0.86 & 0.33 & 2.31 \\
\hline $\begin{array}{l}\text { Business Enterprise } \\
\text { researchers as \% of } \\
\text { national total }\end{array}$ & 59 & 31 & 57.5 & 56.3 & 47.5 & 22.5 & 62.7 \\
\hline $\begin{array}{l}\text { Higher Education } \\
\text { expenditure on R\&D } \\
\text { (HERD) as \% of GDP }\end{array}$ & 0.95 & 0.7 & 0.77 & 0.53 & 0.52 & 0.31 & 0.92 \\
\hline $\begin{array}{l}\text { Higher education } \\
\text { researchers as \% of } \\
\text { national total }\end{array}$ & 37.3 & 55.3 & 30 & 27.7 & 35.4 & 56.9 & 33.6 \\
\hline
\end{tabular}

Source: OECD, 2013 


\section{Research results and discussion}

For the search period of 1972-2014, the total of 932 scientific publications on the issues of interaction between universities and businesses were found in the Scopus database, including 313 'university-industry interaction' (UII) and 619 'university-industry collaboration' (UIC). One of the parameters-'the number of publications', which characterises scientific activity-represents a total value of publications on the topics of 'university-industry interaction' and 'university-industry collaboration', and illustrates the growing scientific interest of researchers in the world to the problem of cooperation between universities and the business community (Fig. 2). The annual number of publications has increased by 70 times in the period from 1974 to 2014 .

The increase in intensity of attention to the research of problems of interaction/ relationship between universities and production (industry) was observed since the late 1990s, when no more than 6-7 articles a year were published. Although a surge of interest in the problem should be noted in some years, particularly in 1986, when 15 papers on the subject of university-industry interactions were published, and in 1989 with 10 published works on the subject of universityindustry collaboration, which notably differs from the other years in this period by $3-5$ times.

Figure 2. Dynamics of publication activity, 1972-2014

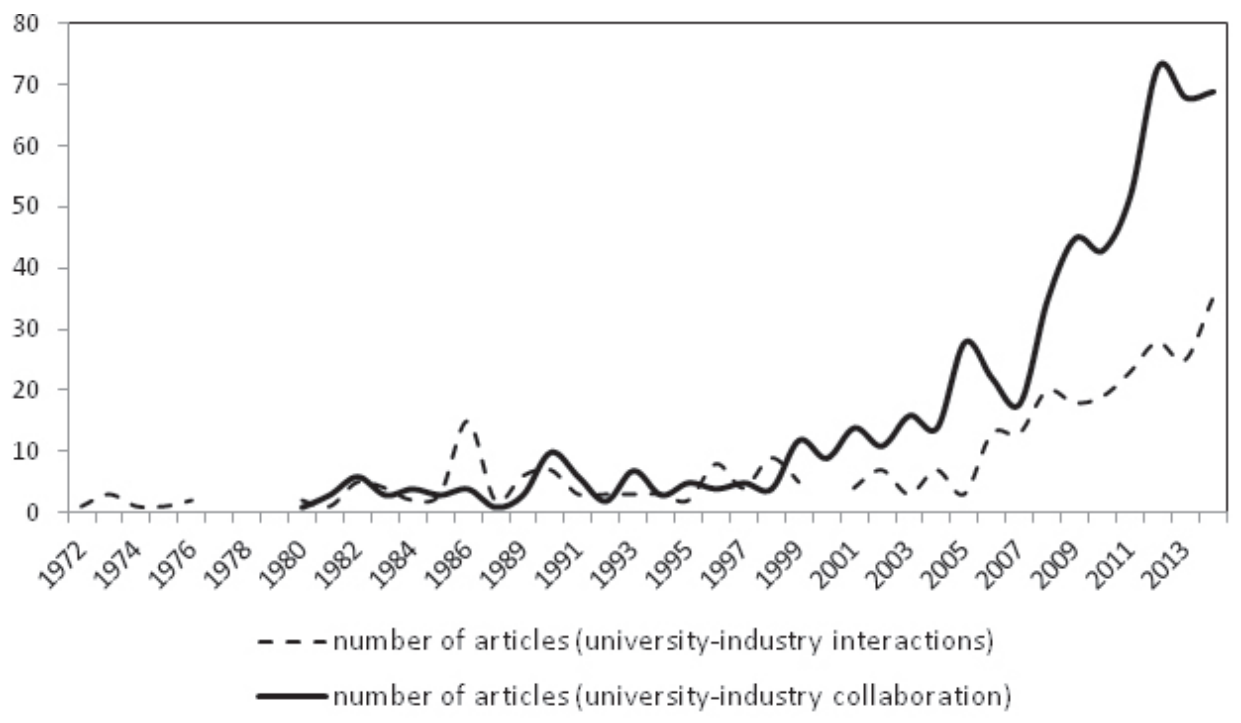

Source: Authors' construction based on Scopus 
Even if there are similarities in the dynamics of scientific interest in the problems of the relationship between universities and businesses, presented as 'university-industry interactions' and 'university-industry collaboration', on the whole, there are differences in time in the increase of intensity of this interest as well (the estimated value of the total number of publications in the world by the method of the direct account, based on Scopus bibliographic data). A rapid growth in interest is observed on the issue of 'university-industry collaboration' since 1998, when 12 works were published (three times more than in the previous year) with a peak in 2014 with 69 works (by 1998, the growth rate was $575 \%$, see Fig. 2).

Much later (since 2006), the interest in the subject of 'university-industry interactions' has intensified with a maximum number of publications occurring in 2014-amounting to 35 publications (an increase of 2.7 times compared to 2006). Based on that fact it can be argued that the interest of the scientific community in this field of research is holding and even rising.

Geographical distribution of publication activity is also interesting. The share of the top 15 countries in the total number of publications on the subject of 'university-industry collaboration' is $86.3 \%$ and on the subject of 'universityindustry interactions' is $92.5 \%$, respectively. The absolute leaders in presentation of research results on the subject of interaction between universities and industry (business) are the authors from the United States: $24.1 \%$ and $17.7 \%$ of the total number of publications, respectively (Fig. 3).

European countries are actively represented in the studies: in the list of the top 15 on the subject of UIC there are 8 European countries $(35.5 \%$ of the publications), in the list of the top 15 on the subject of UII there are 7 European countries ( $41 \%$ of the publications). It should be noted that the second place in both top 15 lists is held by publications of researchers from the United Kingdom (12.8\% and $13.11 \%$ of the publications, respectively).

The articles by researchers from South-East Asia constitute 19.4\% and 27.2\% of the publications, concentrated in five countries with clear dominance of the authors of publications from China and Japan.

Regarding the countries of the Baltic Sea Region, three countries got in the top 15 of the UIC field of research: Sweden (4.2\%), Finland (2.1\%) and Denmark $(1.8 \%)$; the top 15 of the UII field was represented by only two countries: Sweden (4.9\%) and Denmark (2.95\%), reflecting a still not very high activity of the Baltic Sea Region countries in the study of issues of cooperation between universities and businesses. 
Figure 3. Publication activity of top 15 countries, 1972-2014

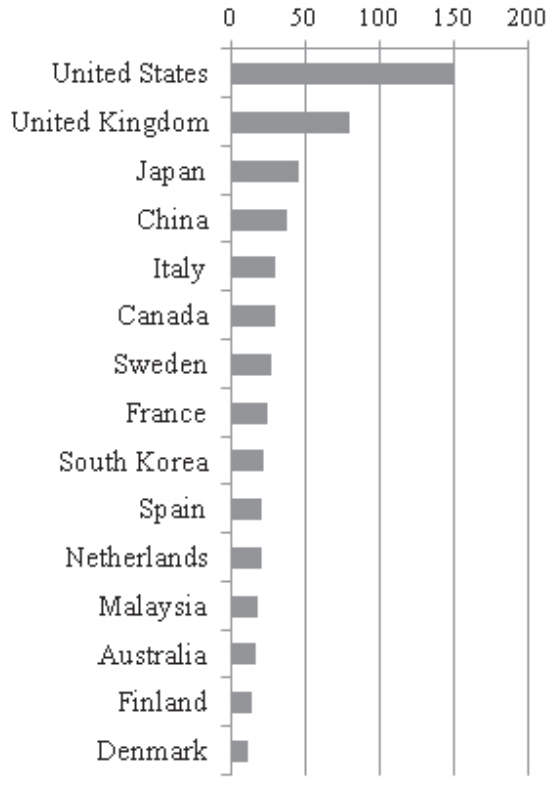

a) university-industry collaboration

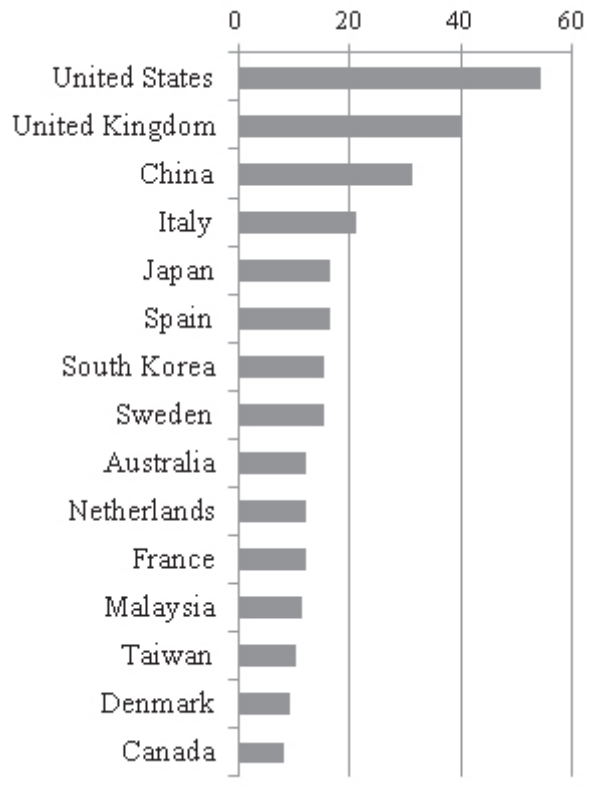

b) university-industry interactions

\section{Source: Authors' construction based on Scopus}

We made an assessment of the publication activity of countries of the Baltic Sea Region for ten years from 2004 to 2014. During this period, the authors from countries of the Baltic Sea Region had published 65 articles related to the study of university-industry collaboration. In contrast to global trends in publication activity in the field of UIC, no growth in the number of publications in these countries is observed: the highest amount (11 articles) was published in 2010, with a trend of further decrease in the number of publications (Fig. 4).

The share of joint scientific publications in the Baltic Sea Region countries on this issue for the period 2004-2010 amounted to $13.9 \%$ of the 467 papers published around the world during the same period. Clearly, the scientific interest in this area of research in the Baltic region has been gradually fading over the past four years (Fig. 4).

An important role in changing the trajectory that characterises the scientific interest of the researchers of the Baltic Sea Region countries in this issue is played by the researchers from Sweden, Finland, Norway, Germany, Denmark (Fig. 5), since the share of research publications in these countries makes $94.03 \%$ 
of the total number of documents published in the countries of the Baltic Sea Region (Fig. 6).

Figure 4. Dynamics of the number of scientific publications from the Baltic Sea Region compared to the countries worldwide, 2004-2014

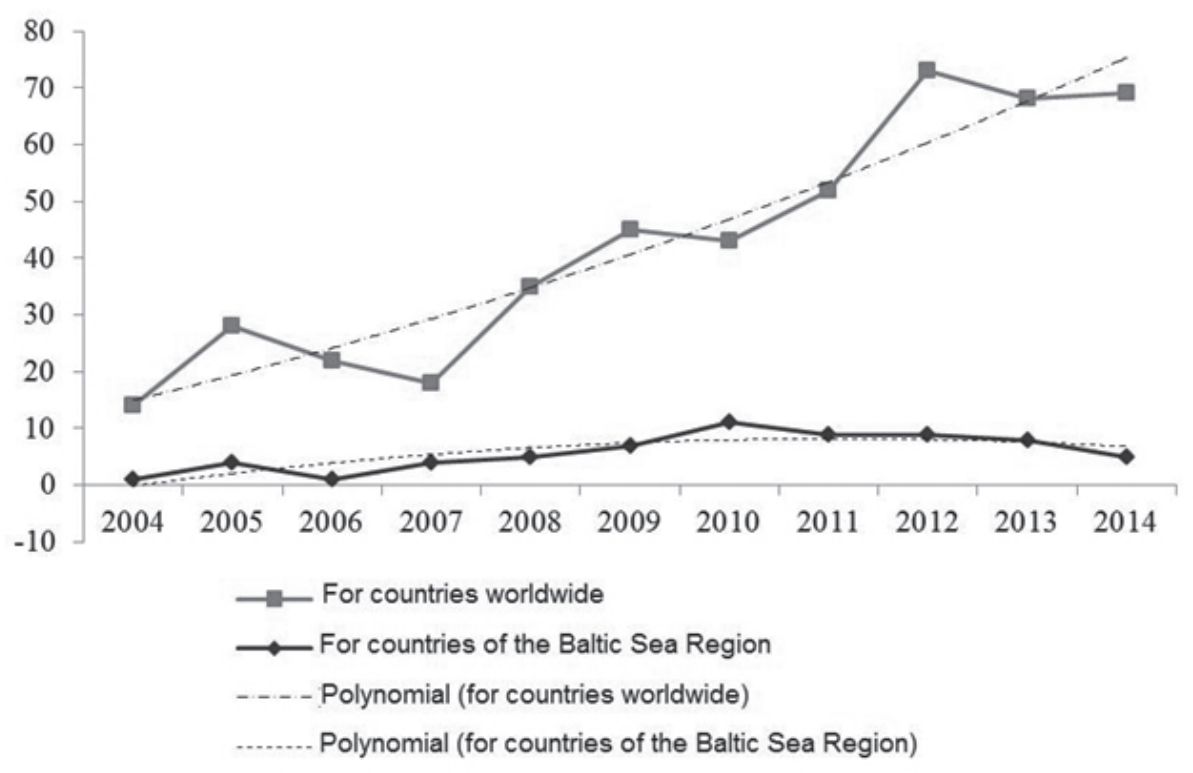

Source: Authors' construction based on Scopus

Figure 5. Dynamics of the number of publications from Denmark, Finland, Norway, Sweden and Germany, 2004-2014

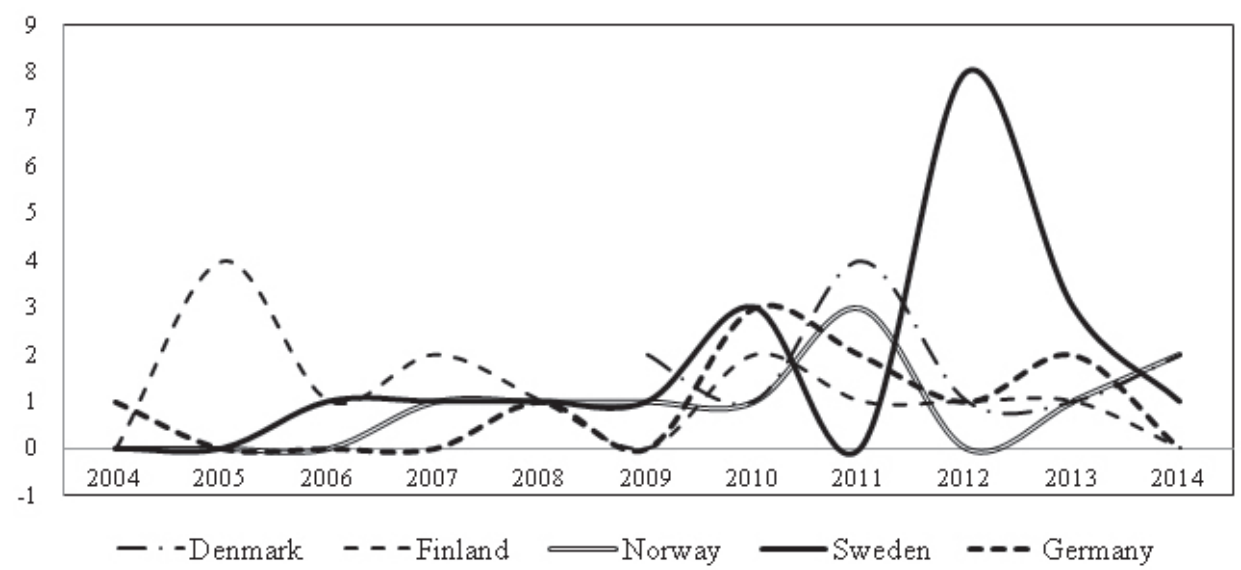

Source: Authors' construction based on Scopus 
Some countries in the Baltic Sea Region do not show active interest in university-industry collaboration problems, which is characterised either by a lack of publications on this subject (Latvia, Iceland) or by a small number of them (Estonia, Lithuania).

Figure 6. The share of scientific publications of the Baltic Sea Region countries, 2004-2014, \%

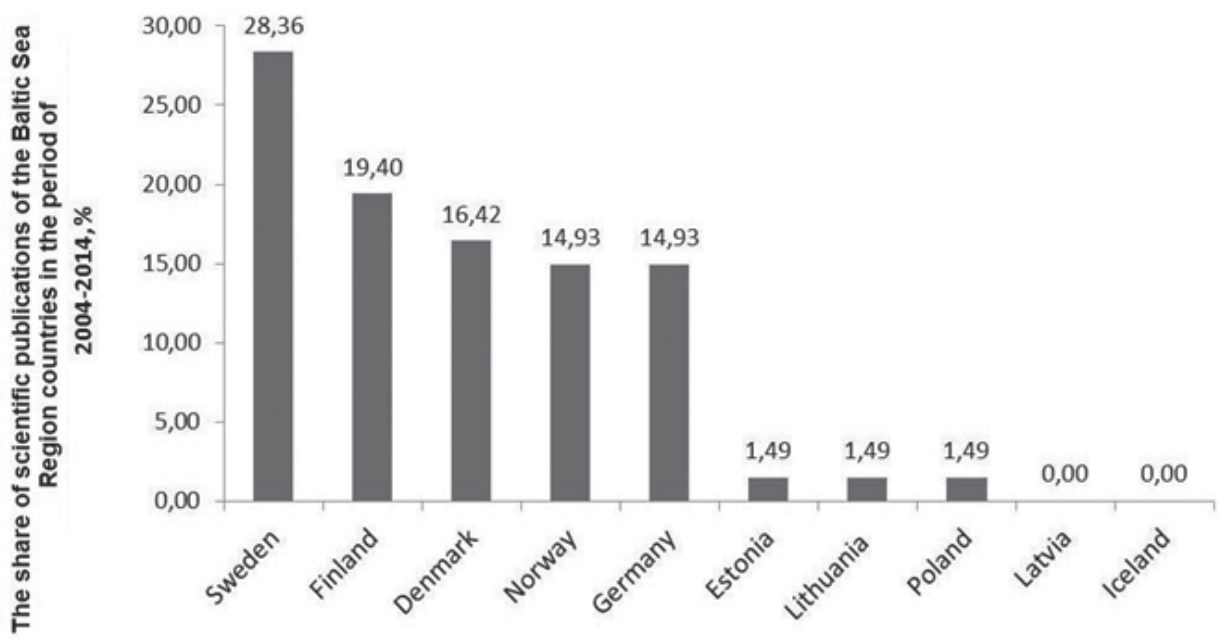

Source: Authors' construction based on Scopus

This indicates a significant heterogeneity of interest in the problems of interaction between universities and business in the Baltic region. The development of research in this field in such countries as Latvia, Iceland, Estonia, and Lithuania is possible by strengthening cooperation ties with researchers from Sweden, Finland, Norway, Denmark and Germany.

The data on the number of publications of individual universities in the respective countries (Table 3) serves as a confirmation of the findings of dominance of Sweden, Norway and Denmark in the field of scientific research and active dissemination of scientific results in matters of collaboration between universities and businesses in this macro-region. 
Table 3. The number of publications of universities and organisations in countries of the Baltic region

\begin{tabular}{|l|l|c|}
\hline Universities, organisations & Country & $\begin{array}{c}\text { Number } \\
\text { of publi- } \\
\text { cations }\end{array}$ \\
\hline The Royal Institute of Technology KTH & Sweden & 7 \\
\hline Lund University & Sweden & 6 \\
\hline Chalmers University of Technology & Sweden & 4 \\
\hline Linköping University & Sweden & 4 \\
\hline $\begin{array}{l}\text { Norwegian Institute for Studies in Innovation, } \\
\text { Research and Education }\end{array}$ & Norway & 4 \\
\hline University of Oslo & Norway & 3 \\
\hline Lappeenranta University of Technology & Finland & 3 \\
\hline University of Gothenburg & Sweden & 3 \\
\hline Aarhus University & Denmark & 3 \\
\hline Copenhagen Business School & Denmark & 3 \\
\hline
\end{tabular}

Source: Authors' construction based on Scopus

Among the universities of this region, half of the Swedish universities are in the top 10 with the highest number of publications $(50 \%)$, Norway and Denmark are represented by 2 universities each, which dedicate their research to cooperation between higher schools and companies, and 1 university is representing Finland. According to the results of such assessments, it is possible to form a communication strategy with leading universities in this field in conducting joint research.

Another indicator of the scientific activity- 'the number of publications in scientific fields related to the analysed problems' allows to determine the areas of scientific knowledge with the highest concentration of research on the analysed issues. The authors have carried out a systematisation of data on the quantity of publications on fields of research and a comparative assessment of changes in the prioritised fields of research in the period of 2000-2004 and for the past five years (2010-2014) (Table 4). It should be noted that, during the analysed periods, the number of scientific fields in which the research on the issues of cooperation between universities and industry was conducted has been expanded from 16 to 24 due to the emergence of such fields as immunology, pharmacology and others. 
According to the data from the abstract database Scopus, in the last 15 years there have been structural changes in the prioritised areas of research devoted to the study of issues of cooperation between universities and business. As of 2014, the main fields of research in the sphere of cooperation are Business, Management and Accounting (42.2\%), Social Sciences (34.3\%), Engineering (30.0\%) and Computer Science (18.8\%), while other subjects do not exceed 7.9\%.

Table 4. The share of publications by fields of research and structural changes in the periods of 2000-2004 and 2010-2014, \%

\begin{tabular}{|l|c|c|c|}
\hline Fields of research & $\mathbf{2 0 0 0 - 2 0 0 4}$ & $\mathbf{2 0 1 0 - 2 0 1 4}$ & $\begin{array}{c}\text { Structural } \\
\text { changes }\end{array}$ \\
\hline Business, Management and Accounting & 23.6 & 42.2 & +18.6 \\
\hline Social Sciences & 22.2 & 34.3 & +12.1 \\
\hline Engineering & 43.1 & 30.0 & -13.0 \\
\hline Computer Science & 25.0 & 18.8 & -6.2 \\
\hline Decision Sciences & 6.9 & 8.3 & +1.3 \\
\hline Economics. Econometrics and Finance & 5.6 & 7.9 & +2.4 \\
\hline Biochemistry, Genetics and Molecular Biology & 5.6 & 0.0 & -5.6 \\
\hline Environmental Science & 0.0 & 5.9 & +5.9 \\
\hline Arts and Humanities & 0.0 & 4.0 & +4.0 \\
\hline Mathematics & 0.0 & 3.6 & +3.6 \\
\hline Others & 22.2 & 18.5 & -3.7 \\
\hline
\end{tabular}

Source: Compiled by the authors according to the data from Scopus

However, if in 2000-2004 research was mainly conducted in the field of 'Engineering' and 'Informatics' (68\%), in the past five years the scientific community of the Baltic Sea Region have been to a greater extent conducting research on the issues of cooperation in the fields of 'Business, Management and Management Accounting' and 'Social Sciences' (76.5\%). Obviously, there is a shift in the main scientific interests in the joint work of universities and industry in almost all areas of research. The study of scientific activity by area of research allows us to analyse and identify relevant areas of research.

Table 5 shows the spread of the publication activity by relevant fields of research of individual countries of the Baltic region. 
Table 5. Structure of the UIC publications by the fields of research in the individual countries the Baltic Sea Region, 2004-2014, \%

\begin{tabular}{|l|c|c|c|c|c|c|}
\hline Subjects & $\begin{array}{c}\text { Total for } \\
\text { the Baltic } \\
\text { Sea } \\
\text { Region }\end{array}$ & Sweden & Finland & Denmark & Germany & Norway \\
\hline $\begin{array}{l}\text { Business, Manage- } \\
\text { ment and Accounting }\end{array}$ & 42.2 & 45.5 & 15.4 & 63.6 & 36.4 & - \\
\hline Engineering & 30.0 & 22.7 & 7.7 & 18.2 & 27.3 & 20 \\
\hline Social Sciences & 34.3 & 22.7 & - & 27.3 & 45.5 & 70 \\
\hline Decision Sciences & 6.9 & 8.6 & 13.1 & 7.2 & - & 10 \\
\hline $\begin{array}{l}\text { Agricultural and } \\
\text { Biological Sciences }\end{array}$ & 6.3 & 9.1 & 7.7 & - & 4.1 & - \\
\hline Computer Science & 18.8 & 9.1 & 30.8 & 27.3 & 18.2 & 10 \\
\hline Arts and Humanities & 4.0 & 4.5 & - & - & - & 10 \\
\hline
\end{tabular}

Source: Authors' construction based on Scopus

A high share of scientific publications in Denmark (63.6\%) on the UIC issues in the field of Business, Management and Accounting indicates a high interest of analysts in this field, and similar conclusions can be drawn about Sweden (45.5), which has higher than the regional average rate of similar publications. In Germany, the interest is mainly focused on Social Sciences (45.5\%), in Finlandon the field of Computer Science (30,8\%) (Table 4) due to the peculiarities of the economic structure, established trends in research and demands of business and scientific community.

An analysis of the publication activity in the field of UIC has shown that researchers from the countries of the Baltic Sea Region collaborated with experts from 15 other countries all over the world including USA, whose experts were co-authors of 6 articles, with UK 4, France 2, and other countries 1 article each. Geographically, there are only the European and American co-authors, but also partners from Asia (Japan, Malaysia, and the Republic of Korea). Central and Latin America (Costa Rica, Mexico), Africa (Egypt, Botswana, South Africa). At the same time, internally the countries of the Baltic Sea Region still retain focus on traditional geographical cooperation, in particular, some publication activity in the investigated field of the study can be observed between Sweden, Norway, Denmark and Finland. Other countries of the Baltic Sea Region are more oriented on other regions (for example, the UK, Netherlands) in scientific cooperation concerning the interaction between universities and business. 
Also, the identification of the subject area of the UIC based on the evaluation of papers with highest rates of citation is not being overlooked in the scope of the present study. According to the results of the search and systematisation of publications with high rates of citation by authors, included in the abstract database Scopus, and after evaluating the content of annotations we identified and systematised key avenues of research in the subject areas corresponding to five-year periods for 2000-2014, (Table 6).

Table 6. Examples of the major subject areas based on the results of citing

\begin{tabular}{|c|c|}
\hline Time period & Examples of subject areas \\
\hline \multirow[b]{2}{*}{ 2000-2004 } & Evaluation of knowledge transfer \\
\hline & $\begin{array}{l}\text { Evaluation of the advantages, main benefits arising from the collaboration } \\
\text { between universities and business }\end{array}$ \\
\hline \multirow{3}{*}{ 2005-2009 } & $\begin{array}{l}\text { The development of entrepreneurial universities while strengthening coopera- } \\
\text { tion between universities and business }\end{array}$ \\
\hline & $\begin{array}{l}\text { Assessment of the impact on the innovativeness of the company products } \\
\text { made by cooperation between universities and business }\end{array}$ \\
\hline & $\begin{array}{l}\text { Analysis of the main determinants of collaboration between universities and } \\
\text { business }\end{array}$ \\
\hline \multirow[t]{2}{*}{ 2010-2014 } & $\begin{array}{l}\text { Assessment of ways to reduce barriers (obstacles) for the cooperation be- } \\
\text { tween universities and business; }\end{array}$ \\
\hline & Assessment of knowledge spreading effects \\
\hline
\end{tabular}

Source: Compiled by the authors according to the data of Scopus

Relevant areas of research in the study of the UIC in the past five years have been issues of the effectiveness of the dissemination of knowledge and the reduction of obstacles for various forms of cooperation, which is a logical development of the subject area over the past 15 years.

It is important to note that the kind of assessment of the qualitative data, such as the assessment of the publications with high rates of citing, allows to orientate oneself in the actual directions of research carried out by the international scientific community.

An important feature of the development of relations between universities and other institutions is a joint publication. An analysis of the co-authorship of publications in the field of UIC in the Baltic Sea Region countries showed that 64 articles were authored by 108 individuals. In the field of UIC, $95.7 \%$ of the authors of articles are concentrated in five countries of the Baltic Sea Region (Table 7). 
The authors of works in the field of UIC are mostly university staff $(71.3 \%)$. or employees of other institutional structures $(27.7 \%)$. The parity publication cooperation is characteristic only of Denmark, where $50 \%$ of co-authorship falls on universities and other academic organisations and companies. This suggests that in the countries of Denmark, Finland, Norway, Sweden and Germany, the cooperation of universities with business and other institutions is implemented practically through involvement in research projects, and this may indicate improvement in the quality of communications. Furthermore, $95.47 \%$ of the total number of authors can be attributed to precisely these countries, which once again confirms that the investigated subject matter is being popularised in these countries. Along with this, a significant gap between science and industry can be seen in other countries, where $100 \%$ of the publications are represented by works from universities.

Table 7. The structure of publishing cooperation between the countries of the Baltic Sea Region, 2004-2014

\begin{tabular}{|l|c|c|c|c|c|c|}
\hline \multirow{2}{*}{ States } & \multicolumn{3}{|c|}{$\begin{array}{c}\text { Number of publications' authors } \\
\text { in the field of UIC }\end{array}$} & \multicolumn{2}{c|}{$\begin{array}{c}\text { Structure of the } \\
\text { authorship,\% }\end{array}$} & \multirow{2}{*}{$\begin{array}{c}\text { Share in the } \\
\text { total number } \\
\text { of authors, } \%\end{array}$} \\
\cline { 2 - 6 } & Total & $\begin{array}{c}\text { Com- } \\
\text { panies, } \\
\text { research } \\
\text { institu- } \\
\text { tions }\end{array}$ & $\begin{array}{c}\text { Universi- } \\
\text { ties }\end{array}$ & $\begin{array}{c}\text { Companies, } \\
\text { research } \\
\text { institutions }\end{array}$ & $\begin{array}{c}\text { Universi- } \\
\text { ties }\end{array}$ & \\
\hline Estonia & 2 & 0 & 2 & 0.0 & 100.0 & 1.85 \\
\hline Latvia & 0 & 0 & 0 & 0.0 & 0.0 & 0.00 \\
\hline Lithuania & 2 & 0 & 2 & 0.0 & 100.0 & 1.85 \\
\hline Denmark & 18 & 9 & 9 & 50.0 & 50.0 & 16.67 \\
\hline Finland & 17 & 4 & 13 & 23.5 & 76.5 & 15.74 \\
\hline Iceland & 0 & 0 & 0 & 0.0 & 0.0 & 0.00 \\
\hline Norway & 17 & 5 & 12 & 29.4 & 70.6 & 15.74 \\
\hline Sweden & 29 & 6 & 23 & 20.7 & 79.3 & 26.85 \\
\hline Germany & 22 & 7 & 15 & 31.8 & 68.2 & 20.37 \\
\hline Poland & 1 & 0 & 1 & 0.0 & 100.0 & 100.0 \\
\hline Total & 108 & 31 & 77 & 27.8 & 71.3 & 100.0 \\
\hline
\end{tabular}

Source: Authors' construction based on Scopus

Following the results of the conducted research and found trends we have been tasked to check whether the parameters characterising research and development, 
presented in Table 2, have any effect on the publication activity of individual countries as well as the extent of this influence. We have chosen the following parameters for the analysis: gross domestic expenditure on R\&D as percentage (marked by \% in the Table) of GDP; total researchers in full-time equivalent per 1,000 total employment; percentage of gross domestic expenditure on R\&D performed by the business enterprise sector; percentage of gross domestic expenditure on R\&D performed by the higher education sector; business enterprise expenditure on R\&D as a percentage of GDP; business enterprise researchers as a percentage of national total; and higher education expenditure on R\&D as a percentage of GDP. We felt it necessary to test the hypothesis that such parameters as gross domestic expenditure on R\&D as percentage of GDP. percentage of gross domestic expenditure on R\&D performed by the business enterprise sector, percentage of gross domestic expenditure on R\&D performed by the higher education sector, business enterprise expenditure on R\&D as a percentage of GDP, higher education expenditure on $R \& D$ as a percentage of GDP are positively correlated with the number of scientific publications and have a significant impact on the publication activity.

To test the hypothesis we have selected data, characterising the selected parameters as of 2012, based on the report data (OECD, 2013), and also on the number of scientific publications according to the data from the abstract database Scopus by countries worldwide. The descriptive statistics for these variables is shown in Table 8 .

With the help of the SPSS statistical analysis (Table 9) during the research in order to study multiple correlation we used rank correlation method-the Kendall rank correlation coefficient, because it is more informative than the definition of correlation made by Pearson and Spearman.

In the case of testing the hypothesis on the significance of rank correlation coefficient, the null hypothesis $\tau=0$ is not rejected if the value of the Kendall correlation coefficient (modulo) falls in the range of acceptable values: $|\tau| \leq \tau 0.05(\mathrm{n})$. Correlation is considered significant if the module of the 'tau' coefficient falls into the critical region: $|\tau|>\tau 0.01(\mathrm{n})$.

Table 9 shows the results of calculation of Kendall's rank correlation for eight variables. The values of correlation coefficients for all variables are significantly different. The results obtained according to the data from selection allow to state that six out of seven parameters have the correlation coefficient value of less than 0.2 and -0.2 , which characterises the virtual absence of any correlation dependence between the number of published papers and analysed indicators. 
Table 8. Descriptive statistics

\begin{tabular}{|c|c|c|c|c|c|c|c|c|}
\hline Variables & 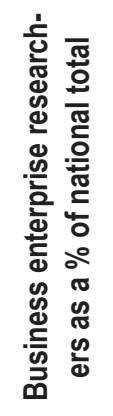 & 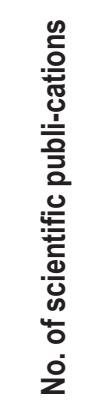 & 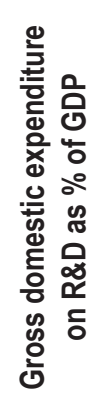 & 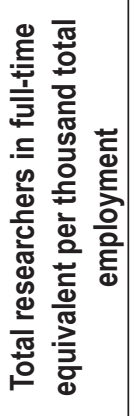 & 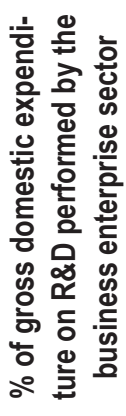 & 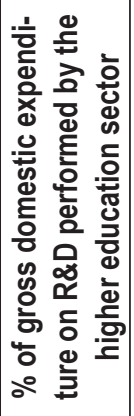 & 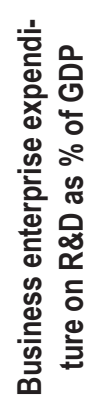 & 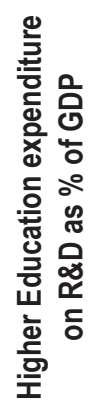 \\
\hline N Valid & 19 & 19 & 19 & 19 & 19 & 19 & 19 & 19 \\
\hline Missing & 0 & 0 & 0 & 0 & 0 & 0 & 0 & 0 \\
\hline Mean & 54.589 & 6.63 & 2.3058 & 8.737 & 63.174 & 24.016 & 1.5447 & .5105 \\
\hline $\begin{array}{l}\text { Std. Error } \\
\text { of Mean }\end{array}$ & 2.7520 & 1.402 & .21613 & .7929 & 2.1208 & 2.3155 & 18280 & .05069 \\
\hline Median & 56.300 & 5.00 & 2.1600 & 8.900 & 64.600 & 26.500 & 1.4800 & .4700 \\
\hline Mode & $35.4^{(\mathrm{a})}$ & 8 & 2.98 & 9.2 & $52.3^{(\mathrm{a})}$ & $7.6^{(\mathrm{a})}$ & $.69^{(\mathrm{a})}$ & $.36^{(\mathrm{a})}$ \\
\hline $\begin{array}{l}\text { Std. } \\
\text { Deviation }\end{array}$ & 11.9955 & 6.112 & .94209 & 3.4561 & 9.2442 & 10.0929 & .79681 & .22097 \\
\hline Variance & 143.893 & 37.357 & .888 & 11.945 & 85.455 & 101.867 & .635 & .049 \\
\hline Range & 42.9 & 24 & 3.44 & 14.3 & 32.8 & 36.3 & 2.98 & .85 \\
\hline Minimum & 35.4 & 1 & .92 & 1.8 & 45.1 & 7.6 & .42 & .10 \\
\hline Maximum & 78.3 & 25 & 4.36 & 16.1 & 77.9 & 43.9 & 3.40 & .95 \\
\hline Sum & 1037.2 & 126 & 43.81 & 166.0 & 1200.3 & 456.3 & 29.35 & 9.70 \\
\hline
\end{tabular}

Note: ${ }^{(a)}$ - Multiple modes exist. The smallest value is shown

The only exception is 'Business enterprise researchers as percentage of national total' variable, the correlation coefficient value of which amounted to +0.348 . This indicates the average level of closeness of the connection and its positive nature. During the study of the significance of the rank correlation coefficient the 'tau' Kendall coefficient module value $\tau=0.044$ falls in the range of acceptable values (Correlation is significant at the 0.05 level (2-tailed)). 
Table 9. Correlations matrix

\begin{tabular}{|c|c|c|c|c|c|c|c|c|c|c|}
\hline & & & 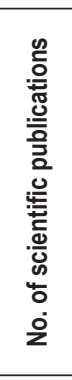 & 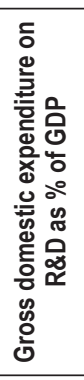 & 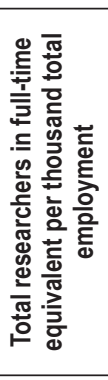 & 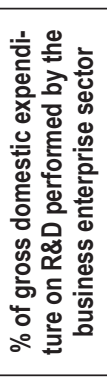 & 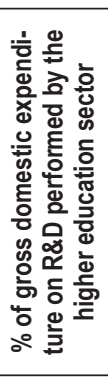 & 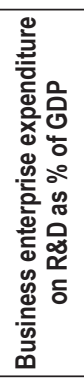 & 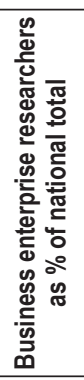 & 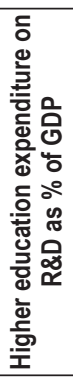 \\
\hline \multirow[t]{24}{*}{$\begin{array}{l}\text { Kendall's } \\
\text { tau_b }\end{array}$} & $\begin{array}{l}\text { Number of scientific } \\
\text { publications }\end{array}$ & $\begin{array}{l}\text { Correlation } \\
\text { Coefficient }\end{array}$ & 1.000 & .147 & -.061 & .227 & -.214 & 166 & $.348\left(^{*}\right)$ & -.178 \\
\hline & & Sig. (2-tailed) & & .396 & .723 & .190 & .216 & .339 & .044 & .304 \\
\hline & & $\mathrm{N}$ & 19 & 19 & 19 & 19 & 19 & 19 & 19 & 19 \\
\hline & $\begin{array}{l}\text { Gross domestic } \\
\text { expenditure on } \\
\text { R\&D as \% of GDP }\end{array}$ & $\begin{array}{l}\text { Correlation } \\
\text { Coefficient }\end{array}$ & .147 & 1.000 & $.547^{(*)}$ & $.602^{(*)}$ & -.305 & $.909^{(*)}$ & $.563^{(*)}$ & $\left..342^{*}\right)$ \\
\hline & & Sig. (2-tailed) & .396 & & .001 & .000 & .069 & .000 & .001 & .042 \\
\hline & & $\mathrm{N}$ & 19 & 19 & 19 & 19 & 19 & 19 & 19 & 19 \\
\hline & $\begin{array}{l}\text { Total researchers in } \\
\text { full-time equivalent } \\
\text { per thousand total } \\
\text { employment }\end{array}$ & $\begin{array}{l}\text { Correlation } \\
\text { Coefficient }\end{array}$ & -.061 & $.547^{(*)}$ & 1.000 & .283 & -.012 & $.496^{(*)}$ & .305 & $.484^{(*)}$ \\
\hline & & Sig. (2-tailed) & .723 & .001 & & .092 & .944 & .003 & .069 & .004 \\
\hline & & $\mathrm{N}$ & 19 & 19 & 19 & 19 & 19 & 19 & 19 & 19 \\
\hline & $\begin{array}{l}\text { \% of gross domes- } \\
\text { tic expenditure on } \\
\text { R\&D performed } \\
\text { by the business } \\
\text { enterprise sector }\end{array}$ & $\begin{array}{l}\text { Correlation } \\
\text { Coefficient }\end{array}$ & .227 & $.602^{(\prime)}$ & .283 & 1.000 & $-.618^{(*)}$ & $.692^{(\prime)}$ & $.559^{(")}$ & -.030 \\
\hline & & Sig. (2-tailed) & .190 & .000 & .092 & & .000 & .000 & .001 & .861 \\
\hline & & $\mathrm{N}$ & 19 & 19 & 19 & 19 & 19 & 19 & 19 & 19 \\
\hline & $\begin{array}{l}\text { \% of gross domes- } \\
\text { tic expenditure on } \\
\text { R\&D performed by } \\
\text { the higher educa- } \\
\text { tion sector }\end{array}$ & $\begin{array}{l}\text { Correlation } \\
\text { Coefficient }\end{array}$ & -.214 & -305 & -.012 & $-.618^{(*)}$ & 1.000 & $-.359^{(*)}$ & -.310 & $.359^{(*)}$ \\
\hline & & Sig. (2-tailed) & .216 & .069 & .944 & .000 & & .033 & .064 & .033 \\
\hline & & $\mathrm{N}$ & 19 & 19 & 19 & 19 & 19 & 19 & 19 & 19 \\
\hline & $\begin{array}{l}\text { Business enterprise } \\
\text { expenditure on } \\
\text { R\&D as \% of GDP }\end{array}$ & $\begin{array}{l}\text { Correlation } \\
\text { Coefficient }\end{array}$ & .166 & $.909^{(*)}$ & $.496^{(")}$ & $.692^{(")}$ & $-.359^{(*)}$ & 1.000 & $.594^{(\prime)}$ & .284 \\
\hline & & Sig. (2-tailed) & .339 & .000 & .003 & .000 & .033 & & .000 & .092 \\
\hline & & $\mathrm{N}$ & 19 & 19 & 19 & 19 & 19 & 19 & 19 & 19 \\
\hline & $\begin{array}{l}\text { Business enterprise } \\
\text { researchers as \% } \\
\text { of national total }\end{array}$ & $\begin{array}{l}\text { Correlation } \\
\text { Coefficient }\end{array}$ & $.348^{(\prime)}$ & $.563^{(*)}$ & .305 & $.559^{(\prime \prime)}$ & -.310 & $.594^{(\prime)}$ & 1.000 & .182 \\
\hline & & Sig. (2-tailed) & .044 & .001 & .069 & .001 & .064 & .000 & & .278 \\
\hline & & $\mathrm{N}$ & 19 & 19 & 19 & 19 & 19 & 19 & 19 & 19 \\
\hline & $\begin{array}{l}\text { Higher education } \\
\text { expenditure on } \\
\text { R\&D as \% of GDP }\end{array}$ & $\begin{array}{l}\text { Correlation } \\
\text { Coefficient }\end{array}$ & -.178 & $.342^{(*)}$ & $.484^{(*)}$ & -.030 & $.359^{(\prime)}$ & .284 & 182 & 1.000 \\
\hline & & Sig. (2-tailed) & .304 & .042 & .004 & .861 & .033 & .092 & .278 & \\
\hline & & $\mathrm{N}$ & 19 & 19 & 19 & 19 & 19 & 19 & 19 & 19 \\
\hline
\end{tabular}

Correlation is significant at the 0.05 level (2-tailed)

" Correlation is significant at the 0.01 level (2-tailed)

Tallinn University of Technology (ISSN 2228-0588), Vol. 7, No. 2 (23) 
This confirms the connection between the number of scientific publications and 'Business enterprise researchers as a percentage of national total' variable - that is, this proves that the publication activity may have a correlation dependence on the 'Business enterprise researchers as a percentage of national total' variable. However, the obtained results of research refute our hypothesis of high dependence of publication activity on different kinds of expenses for research and development. The reason for these results may be that a very narrow thematic area (university-industry interaction) was considered in the framework of the study, rather than, for example, medicine, chemistry, physics, etc., which are mainstream and the high financial costs of research in these areas are the most evident. In addition, the analysis results are in many ways caused by the quality of samples and the selection of analysed variables. In this situation, further studies could test the methodology and the obtained results using more comprehensive databases with the selection of new variables.

\section{Conclusions, proposals, recommendations}

This work provides a systematised data on the nature of trends and patterns in the priorities of researchers from the countries of the Baltic Sea Region in the context of integration of these countries, as well as the position of the Baltic Sea Region countries amid the global trends of studies of the university-industry collaboration. The work is based upon the research of data on the number of scientific publications in the fields of UII and UIC from countries all over the world (1972-2014), as well as from the countries of the Baltic Sea Region (2004-2014) on the basis of the data from the indexing database Scopus.

The main objective of the article shows the results of the level of scientific interest of researchers from the Baltic Sea Region to the issues of interaction between the university and industry, and focuses on the main trends of scientific cooperation in this field. In addition to the main task, the authors have tried to assess the degree of involvement of the universities and representatives of different institutions and companies, interested in this knowledge, in joint research.

As a result of the research, the following trends were identified:

- The article shows relatively high publication activity in the world, associated with research of the problems of 'university-industry interactions' and 'university-industry collaboration' for the period 1972-2014. An increase 
in attention to research of these issues has been observed since the late 1990s. On the issue of 'university-industry collaboration', a rapid growth of interest has been observed since 1998, when 12 works were published (three times more than in the previous year) with a peak in 2014 with 69 works (by 1998, the growth rate reached 575\%).

- The absolute leaders in presenting the results of research in the field of interaction between universities and industry (business) for the period 1972-2014 were authors from the USA with $24.1 \%$ and $17.7 \%$ of the total number of papers published in the world, respectively. Among the top 15 countries working in this area the following countries of the Baltic Sea Region stand out: Sweden (4.2\%), Finland (2.1\%) and Denmark (1.8\%).

- The share of scientific publications of the Baltic Sea Region countries on this issue over the period of 2004-2010 amounted to $13.7 \%$ of the total number of articles published in the world during this period. In contrast with the global trends of publication activity in the field of universityindustry collaboration, an unsustainable trend in the number of publications is observed in the countries of the Baltic Sea Region: the highest number (11 papers) was published in 2010, with a trend of further decrease in the number of publications up to 2014. An important role in the formation of this tendency is played by researchers from Sweden, Finland, Norway, Denmark, and Germany, the share of publications of which accounts for 95.5\% of the total number of articles published by the countries of the Baltic Sea Region. This proves that the dominant role in shaping of the trends of scientific interest in the subject of university-industry collaboration is retained by the Scandinavian countries and Germany. The most dynamic period of the scientific activity in the region falls on the period from 2011 to 2014 .

- Among the main areas of research on the subject of university-industry collaboration, the researchers from the Baltic Sea Region allocate Business, Management and Accounting (42.2\%), Social Sciences (34.3\%), Engineering (30.0\%) and Computer Science (18.8\%), while other subjects do not exceed $7.9 \%$.

- According to the results of the search and systematisation of publications with high rates of citation by authors, included in the indexing database Scopus, and after evaluating the content of annotations, issues of the effectiveness of the dissemination of knowledge and the reduction of obstacles for various forms of cooperation became the most relevant areas of research in the study of the UIC in the past five years, which is a logical development of the subject area over the last fifteen years;

- The results of the analysis showed a high degree of international 
cooperation of scientists on the basis of joint scientific publications from countries of the Baltic Sea Region with partners from USA, UK and a number of other European countries as well as Asia, Central and Latin America, and Africa. It is especially typical of Sweden, Finland, Germany, Norway and Denmark. However, in the countries of the Baltic Sea Region the integration processes within the region under the research on the subject of university-industry collaboration can be poorly traced.

- An important characteristic of the development of relations between universities and other institutions is joint publications. Studies have shown that the authors of works on the subject of UIC are mostly university staff (71.3\%) and employees of other institutional structures (27.7\%) for the countries of Finland, Norway, Sweden and Germany. Parity publication cooperation is typical only of Denmark. Thus, in these countries the cooperation of universities with business and other institutions is implemented through their involvement in research projects, and this fact may indicate the raising quality of communications.

- The correlation analysis of the impact of a number of variables on the publication activity in the field of interaction between universities and business (industry) has shown that in this specific area the publication activity is only affected by 'Business enterprise researchers as a percentage of national total' (correlation coefficient +0.348 ), and the rest of the factors taken into account in the research have practically no influence on the publication activity. The analysis results disproved our hypothesis about the high degree of dependence of the publication activity on the different types of expenses for research and development. Furthermore, the study results are for the most part determined by the quality of samples and the selection of variables analysed. In this situation, further studies could test the methodology and the results obtained using more comprehensive databases with the selection of new variables.

Elena Murashova, $\mathrm{PhD}$ in Economics, is associate professor in Economics at the Pacific National University. She received her PhD (Faculty of Economics, Pacific National University ) in 2007. She specialises in universities-business interaction and is involved in the research in competitiveness of higher education.

Valeria Loginova, $\mathrm{PhD}$ in Economics, is associate professor in Economics at the Pacific National University. Her main research interests predominantly focus on issues related to competitiveness of economic systems and universities-business interaction. 


\section{References}

Alcaraz-Rodriguez, R.; Villasana, M. \& Alvarez, M. (2014), 'The significance of the university environment for entrepreneurship education: a case study of an entrepreneurial university in Mexico,' in A. Meerman \& T. Kliewe (eds.) Fostering University-Industry Relationships, Entrepreneurial Universities and Collaborative Innovation, UIIN Good Practice Series 2014, Amsterdam: University Industry Innovation Network, pp. 107-118.

BSR STAR (2015), Innovation in the Baltic Sea Region. Retrieved from http://www. bsrstars.se/project/facts-figures-2/ [accessed 28 Mar 2015]

Butcher, J. \& Jeffrey, P. (2005), 'The use of bibliometric indicators to explore industryacademia collaboration trends over time in the field of membrane use for water treatment,' Technovation, vol. 25, no. 11, pp. 1273-1280.

https://doi.org/10.1016/j.technovation.2004.06.003

Calvert, J. \& Patel, P. (2002), 'University-industry research collaborations in the UK,' Report on Phase 1 of a project funded by EPSRC/ESRC Contract No. P015615, Brighton: SPRU.

(2003), 'University-industry research collaborations in the UK: bibliometric trends,' Science and Public Policy, vol. 30, no. 2, pp. 85-96.

https://doi.org/10.3152/147154303781780597

Communication COM(2009) 248 final from the Commission to The European Parliament, The Council, The European Economic and Social Committee and The Committee of the Region concerning the European Union Strategy for the Baltic Sea Region, Brussels, 10.6.2009. Retrieved from http://ec.europa.eu/regional_policy/sources/ docoffic/official/communic/baltic/com_baltic_en.pdf [accessed $28 \mathrm{Mar} 2015$ ]

De Fuentes, C. \& Dutrénit, G. (2012), 'Best channels of academia-industry interaction for long-term benefit,' Research Policy, vol. 41, no. 9, pp. 1666-1682. https://doi. org/10.1016/j.respol.2012.03.026

Diem, A. \& Wolter, S. C. (2011), The Use of Bibliometrics to Measure Research Performance in Education Sciences, Leading House Working Paper, no. 66, Aarau: Swiss Coordination Centre for Research in Education (SCCRE).

Etzkowitz, H. (2003), 'Innovation in innovation: the Triple Helix of university-industrygovernment relations,' Social Science Information, vol. 42, no. 3, pp. 293-337.

- (2011), 'Triple helix model,' Innovation, no. 4, pp. 5-10.

Etzkowitz, H. \& Leydesdorff, L. (2000), 'The dynamics of innovation: from National Systems and "Mode 2" to a Triple Helix of university-industry-government relations,' Research Policy, vol. 29, no. 2, pp. 109-123. https://doi.org/10.1016/ S0048-7333(99)00055-4 
Feng, F.; Zhang, L.; Du, Y. \& Wang, W. (2015), 'Visualization and quantitative study in bibliographic databases: A case in the field of university-industry cooperation,' Journal of Informetrics, vol. 9, no. 1, pp. 118-134. https://doi.org/10.1016/j.joi.2014.11.009

Fiaz, M. (2013), 'An empirical study of university-industry R\&D collaboration in China: Implications for technology in society,' Technology in Society, vol. 35, no. 3, pp. 191-202. https://doi.org/10.1016/j.techsoc.2013.03.005

Hall, B. H.; Link, A. N. \& Scott, J. T. (2001), 'Barriers inhibiting industry from partnering with universities: evidence from the Advanced Technology Program,' Journal of Technology Transfer, vol. 26, nos. 1-2, pp. 87-98. https://doi.org/10.1023/A:1007888312792

Hameri, A.-P. (1996), 'Technology transfer between basic research and industry,' Technovation, vol. 16, no. 2, pp. 51-57. https://doi.org/10.1016/0166-4972(95)00030-5

Holmes, R. (2014), 'U-Multirank - A university ranking evaluation,' University World News, 12 September, no. 334.

Interreg Baltic Sea Region (n.d.), Programme for 2014 to 2020. Retrieved from http:// eu.baltic.net/Interreg-Baltic-Sea-Region-2014-2020.26029.html [accessed 28 Mar 2015]

Jones-Evans, D.; Klofsten, M.; Andersson, E. \& Pandya, D. (1999), 'Creating a bridge between university and industry in small European countries: the role of the Industrial Liaison Office,' $R \& D$ Management, vol. 29, no. 1, pp. 47-56. https://doi.org/10.1111/1467-9310.00116

Katz, J. S. \& Martin, B. R. (1997), 'What is a research collaboration?' Research Policy, vol. 26, no. 1, pp. 1-18. https://doi.org/10.1016/S0048-7333(96)00917-1

Kerikmäe, T.; Hamulak, O. \& Chochia, A. (2016), 'A historical study of contemporary human rights: deviation or extinction,' Acta Baltica Historiae et Philosophiae Scientiarum, vol. 4, no. 2, pp. 98-115. https://doi.org/10.11590/abhps.2016.2.06

Kostoff, R. N.; Toothman, D. R.; Eberhart, H. J. \& Humenik, J. A. (2001), 'Text mining using database tomography and bibliometrics: a review,' Technological Forecasting and Social Change, vol. 68, no. 3, pp. 223-253. https://doi.org/10.1016/S0040-1625(01)00133-0

Meredith, S. \& Burkle, M. (2008), 'Building bridges between university and industry: theory and practice,' Education+Training, vol. 50, no. 3, pp. 199-215. https://doi.org/10.1108/00400910810873982

Merriam-Webster (n.d.), 'Collaboration,' An Encyclopedia Britannica Company. Retrieved from http://www.merriam-webster.com/thesaurus/collaboration [accessed 21 Apr 2015]

Morris, S.; DeYong, C.; Wu, Z.; Salman, S. \& Yemenu, D. (2002), 'DIVA: a visualization system for exploring document databases for technology forecasting,' 
Computers \& Industrial Engineering, vol. 43, no. 4, pp. 841-862. https://doi. org/10.1016/S0360-8352(02)00143-2

Mowery, D. C. \& Sampat, B. N. (2004), 'Universities in national innovation systems,' Proceedings of the the First Globelics Academy, PhD School on National Systems of Innovation and Economic Development, Lisbon, Portugal, 25 May - 4 June 2004. Retrieved from http://hdl.handle.net/1853/43161 [accessed 28 Mar 2015] (2005), 'Universities in national innovation systems,' in J. Fagerberg, D. C. Mowery \& R. R. Nelson (eds.) The Oxford Handbook of Innovation, New York: Oxford University Press, pp. 209-239.

Muravska, T. \& Prause, G. (2012), European Integration and Baltic Sea Studies: University-Business Partnership through the Triple Helix, Berlin: Berliner Wissenschafts-Verlag.

OECD (2013), Main Science and Technology Indicators: 2014, no. 1, Paris: OECD Publishing.

Orecchini, F.; Valitutti, V. \& Vitali, G. (2012), 'Industry and academia for a transition towards sustainability: advancing sustainability science through universitybusiness collaborations,' Sustainability Science, vol. 7, supplement 1, pp. 57-73.

Pendlebury, D. A. (2008), Using Bibliometrics in Evaluating Research, Philadelphia: Thomson Scientific, Research Department.

Polt, W.; Rammer, C.; Schartinger, D.; Gassler, H. \& Schibany, A. (2001), Benchmarking Industry-Science Relations in Europe: The Role of Framework Conditions, Brussels: DG Enterprise. Retrieved from ftp://ftp.cordis.lu/pub/ improving/docs/ser_conf_bench_polt.pdf [accessed 22 May 2004]

Pritchard, A. (1969), 'Statistical bibliography or bibliometrics,' Journal of Documentation, vol. 25, no. 4, pp. 348-349.

Qin, J.; Lancaster, F. W. \& Allen, B. (1997), 'Types and levels of collaboration in interdisciplinary research in the sciences,' Journal of the American Society for Information Science, vol. 48, no. 10, pp. 893-916. https://doi.org/10.1002/ (SICI)1097-4571(199710)48:10<893::AID-ASI5>3.0.CO;2-X

Rappert, B.; Webster, A. \& Charles, D. (1999), 'Making sense of diversity and reluctance: academic-industrial relations and intellectual property,' Research Policy, vol. 28, no. 8, pp. 873-890. https://doi.org/10.1016/S0048-7333(99)00028-1

Säär, A. \& Rull, A., (2015), 'Technology transfer in the EU: exporting strategically important ICT solutions to other EU Member States,' Baltic Journal of European Studies, vol. 5, no. 2(19), pp. 5-29. https://doi.org/10.1515/bjes-2015-0011

Scott, A.; Steyn, G.; Geuna, A.; Brusoni, S. \& Steinmueller, E. (2001), The Economic Returns to Basic Research and the Benefits of University-Industry Relationships. Report for the Office of Science and Technology, University of Sussex: SPRU (Science and Technology Policy Research). Retrieved from http://www.sussex. ac.uk/spru/publications/econreturnsost.pdf [accessed 22 May 2004] 
Senker, J.; Faulkner, W. \& Velho, L. (1998), 'Science and technology knowledge flows between industrial and academic research: a comparative study,' in H. Etzkowitz, A. Webster \& P. Healey (eds.) Captilizing Knowledge: New Intersections of Industry and Academia, Albany, New York: State University of New York Press, pp. 111-132.

Smorodinskaya, N. (2012), 'The global paradigm shift and the emanation of the network economy,' Journal of Economic Sociology, vol. 13, no. 4, pp. 95-115.

The Global Innovation Index (2015), Effective Innovation Policies for Development, Fontainebleau, Ithaca \& Geneva: Cornell University, INSEAD \& WIPO.

World Economic Forum (2006), The Global Competitiveness Report 2006-2007, Geneva.

- (2008), The Global Competitiveness Report 2008-2009, Geneva. (2009), The Global Competitiveness Report 2009-2010, Geneva. (2010), The Global Competitiveness Report 2010-2011, Geneva. (2011), The Global Competitiveness Report 2011-2012, Geneva. (2012), The Global Competitiveness Report 2012-2013, Geneva. (2013), The Global Competitiveness Report 2013-2014, Geneva. (2014), The Global Competitiveness Report 2014-2015, Geneva. 